\title{
INFORMAL SECTOR AND INTERNATIONAL CAPITAL MOVEMENT: NEW EVIDENCE FROM SOME PETROLEUM COUNTRIES
}

\author{
Ahmed Amine ZEDDAM ${ }^{1}$, Mohamed Driouche DAHMANI ${ }^{2}$, \\ Abdelatif HAMRIT ${ }^{3}$ \\ ${ }^{1,2,3}$ Djelali Liebes University, Sidi Bel Abbes, Algeria \\ Corresponding author e-mail: ahmed.zeddam@univ-sba.dz
}

\begin{abstract}
The main aim of this paper is to investigate the effect of the informal economy (IE) on foreign direct investment (FDI) in a sample of petroleum producing countries (Algeria, Norway, the Russian Federation, Saudi Arabia and United States) based on data covering the period of 1991-2018 and using the Non-linear Autoregressive Distribution Lag (NARDL) model. The NARDL model was built separately for each country in the study sample. The main finding of this study is the impact of IE size on FDI inflows in all of the countries in the study sample, even if they are all producing and exporting countries. The empirical results lead to distinguish between two sub-groups. The first sub-group consists of countries whose FDI inflows have been positively affected by positive and negative shocks in the IE. These countries are characterised by a high share of natural resources in their GDP. The second sub-group consists of countries whose inward FDI has been positively affected by negative shocks in the IE and negatively affected by the positive ones. The most common feature of this subgroup is the relative independence of economics from natural resources.
\end{abstract}

Keywords: Informal economy (IE); Foreign direct investment (FDI); Non-linear Autoregressive Distribution Lag (NARDL); International capital movement.

JEL Classification: O17, E26, C22, F3, F21

\section{INTRODUCTION}

International capital movements began to rise significantly since the early 1980 s, with the abandonment of the communist system by some communist countries, and the beginning of their entry into the market economy. The international institutions had accompanied these countries in their economic transition by providing the necessary mechanisms to achieve the capital. To address some economic, financial, and social issues, governments seek to attract international capital. According to the economists, international capital can provide jobs and income opportunities to people, thus increasing household consumption and the general demand. It can be a good way to transfer knowledge and technology (Osano \& Koine 2016). The FDI is the most important aspect of capital movement; and it can be in two ways: inflow FDI and outflow FDI. Many definitions have been given to the FDI. The following definition has been provided by OECD (2019): "Foreign direct investment is a category of investment that reflects the 
objective of establishing a lasting interest by a resident enterprise in one economy (direct investor) in an enterprise (direct investment enterprise) that is resident in an economy other than that of the direct investor". Imad (2002) defined FDI as follows, "FDI is the process whereby residents of one country (the source country) acquire ownership of assets for the purpose of controlling the production, distribution and other activities of a firm in another country (the host country)". The definition of FDI was also given by the World Trade Organization, which is "FDI occurs when an investor based in one country (the home country) acquires an asset in another country (the host country) with the intent to manage that asset". The simplest definition of FDI is "FDI is the establishment of a new business abroad" provided by Bradley (2005). Many influencing factors play an important role in attracting FDI, such as availability of natural ressorces. The researchers (Asiedu \& Lien, 2011) proved that availability of natural resources in an economy was an attractive element to FDI. Human capital also has a positive nexus with the FDI and they reinforce each other (Kheng et al., 2016). Institutional quality also has a significant impact on FDI; thus, the high institutional quality leads to more incoming FDI Peres et al., 2018). In addition to institutional quality, the political stability is very important. Williams (2017) proved that the political instability reduced the FDI inflows. Infrastructure is another important factor in attracting FDI. Rehman et al. (2011) proved a powerful positive effect of infrastructure in attracting FDI, in the case of Pakistan. FDI is very sensible to economic freedom. Economic freedom is one of the critical requirements to attract FDI (Muslija, 2018). These are some influential factors controlling FDI. Although scholars have attached greater importance to studying FDI, studies dedicated to exploring the relationship between FDI and IE are not only few, but rare.T Thus, this subject needs more attention from researchers due to the ambiguous nature of IE.

Since the publishing of the ILO report 1972, the IE as a theme has taken a great attention by researchers, although of this attention the IE stayed keeping its ambiguous feature. The informal ecomomy size is about one third of global GDP, and sometimes its size records extraordinary levels as it happened in Bolivia, wherethe size of IE exceeded 70 \% during the years 1992, 1993, 1994 and 2001, with an average of $62.28 \%$ during the period of 1991-2015 (Medina \& Schneider, 2018). The IE gives an incom opportunities for about $70 \%$ of the world work force (Loayza, 2016). The most common definition of IE was provided by ILO in the $15^{\text {th }}$ International Conference of Labour Statisticians (ICLS), and which was adopted by a large part of scholars. The ICLS defines operating firms in the IE as follows: "private unincorporated enterprises that are unregistered or small in terms of the number of employed persons" (ILO, 2012). This definition is based on the identification of the informal firm to define the IE; another definition of the IE based on the definition of informal activities is as follows: "those economic activities and the income derived from them that circumvent or otherwise avoid government regulation, taxation or observation" (Feige, 1989). In the same context, the IE can be defined as "all currently unregistered economic activities that would contribute to the officially calculated (or observed) Gross National Product if observed" (Frey \& Pommerehne, 1984). Many causes lead to the spread of the IE. The most known factor is tax burden. All studies published in this field come to 
consensus that tax burden is the first influencer of IE size. The contribution of taxes and social security contribution to the IE size was estimated between $45 \%$ and $52 \%$; and the contribution of intensity of regulation to the size of the IE size was estimated between $10 \%$ and $15 \%$ (Enste, 2018). Ruge (2010) proved that intensity of regulation is among the most important influencing factors in the size of IE, and the unemployment rate is associated with the size of IE. The unemployment and IE have positive relationship particularly in the long term (Lisi, 2015). The study of Berdiev (2018) shows that the economic freedom is an influencer of the size of the IE. In addition to previous factors, there are some other causes such as tax system complexity, lower deterrence, corruption, good governance, state subsidy, etc.

\section{LITERATURE REVIEW}

Despite the vast amount of research devoted to the study of FDI and its relationship with economic, social, and political phenomena such as economic growth (Osei \& Kim, 2020; Awunyo-Vitor \& Sackey, 2018; Apergis et al., 2008; Michael, 2018); financial policy (Davies et al., 2021; Desbordes \& Wei, 2017; (Yao et al., 2021); unemployment and demographic changes (Sadikova et al., 2017; Schmerer, 2014; Alsan et al., 2006; Alfalih \& Bel Hadj, 2020); governance and political institution (Kuvvet, 2021; Li et al. 2018; McCloud et al., 2018), only a few have studied the relationship between FDI and IE. Some studies that have dealt with the nexus between FDI and IE are discussed below.

The first study that dealt with the relationship between the FDI and shadow economy used panel data from 145 economies during the period of 1999-2005 (Nikopour et al., 2009). Using Generalized Method of Moments (GMM), the empirical results showed a significant positive effect of IE on FDI, and Granger causality test confirmed that IE caused FDI.

Based on the gravity theory which predicts bilateral trade flows based on the economic size of two countries, and with the purpose of examination of the link between FDI and IE in the OECD countries for the period of 1999-2007, using panel data from 34 OECD countries, the scholars Ali and Bohara (2017) used the Fully Generalized Least Square model (FGLS) and found a positive relationship between FDI and IE. They concluded that an increase in IE by $1 \%$ in the host economy relative to the investor economy led to increasing the incoming FDI by $0.0571 \%$.

For the Asian case, the study used the ARDL model, and Error Correction Model (ECM) to find the relationship between FDI and IE, on the basis of data taken from 19 Asian countries during a period of 2002-2015 (Huynh et al., 2019). In contrast to previous studies, the researchers found a significant negative link between FDI and IE.

There was also research conducted to investigate the effect of IE on specified kind of FDI - Greenfield Investment and Mergers and Acquisitions (M\&As) (Cuong et al., 2020). The study covered 158 economies all over the world, during the period from 2003 to 2018 . The study concluded that IE had a negative effect on M\&As and a positive effect on Greenfield Investment. 
In their paper, Bayar et al. (2020) examined the impact of IE and human development on FDI in a sample of 11 post-communist economies, by using panel data covering the period from 1995 to 2015 . The empirical study concluded that IE and human development were significant determinants to attract FDI, and the longrun analysis showed a negative effect of IE on FDI, but FDI was positively affected by human development.

\section{ESTIMATION METHODOLOGY AND DATA}

\subsection{Methodology: The NARDL Co-integration Model Developed by Shin et al. (2014)}

In order to investigate the effect of the IE on the FDI inflows in a sample of petroleum producing countries, NARDL model has been used in this study. The model allows examining the effects in the short and long run, as well as exploring a response of FDI inflows to positive and negative shocks of IE (Shin et al., 2014):

$$
F D I_{t}=f\left(I E_{t}^{+}, I E_{t}^{+}, \text {Growth }_{t}, \varepsilon_{t}\right) .
$$

The empirical model is represented as follows:

$$
\begin{aligned}
& \Delta F D I_{t}=c+\alpha_{1} I E_{t-1}+\alpha_{2} I E_{t-1}^{+}+\alpha_{3} I E_{t-1}^{-}+\sum_{i=1}^{q} \eta_{i} \Delta I E_{t-i}+ \\
& \sum_{i=1}^{q_{1}} \omega_{1}^{+} I E_{t-i}^{+}+\sum_{i=1}^{q_{1}} \omega_{1}^{-} F D I_{t-i}^{-}+\alpha_{4} \text { Growth }_{t-1}+\varepsilon_{t} .
\end{aligned}
$$

The positive and negative shocks of IE are calculated as follows:

$$
\left\{\begin{array}{l}
I E_{t}^{+}=\sum_{j=1}^{t} \Delta I E_{t}^{+}=\sum_{j=1}^{t} \max \left(\Delta I E_{\mathrm{j}}, 0\right) \\
I E_{t}^{-}=\sum_{j=1}^{t} \Delta I E_{t}^{-}=\sum_{j=1}^{t} \min \left(\Delta I E_{\mathrm{j}}, 0\right)
\end{array},\right.
$$

where:

$\Delta$ represents the first differentiation;

FDI represents foreign direct investment inflow to the country as a percentage of official GDP;

IE represents the size of the informal economy in the country as a percentage of official GDP;

Growth represents the annual percentage growth rate.

\subsection{Data Description}

This paper aims at exploring the impact of IE on FDI inflows in a sample of petroleum producing countries, using data taken from three sources: FDI as a percentage of official GDP and growth rate were extracted from the World Bank web site (2021); the size of IE as percentage of official GDP was gathered from the studies (Medina \& Schneider, 2018; Kahina \& Saïd, 2020). The original time series were annual data, which were converted into quarterly data using EVIEWS 11 software.

When starting this study, the aim was to explore the effect of IE on FDI in OPEC countries plus the Russian Federation and the United States. Due to nonstationary variables related to most of these countries, the study was limited only to 
countries whose variables were stationary. Thus, the counties unde investigation are Algeria, Norway, the Russian Federation, Saudi Arabia and the United States.

Table 1. Sources of Data

\begin{tabular}{|l|l|l|}
\hline Variable & \multicolumn{1}{|c|}{ Description } & \multicolumn{1}{c|}{ Source } \\
\hline FDI & $\begin{array}{l}\text { Foreign direct investment net } \\
\text { inflows as a percentage of } \\
\text { official GDP }\end{array}$ & $\begin{array}{l}\text { World Bank } \\
\text { https://databank.worldbank.org/home.aspx }\end{array}$ \\
\hline IE & $\begin{array}{l}\text { The size of informal economy as } \\
\text { percentage of official GDP }\end{array}$ & $\begin{array}{l}\text { All informal economy data except the data for } \\
\text { Algeria from 2016 to 2018 were taken from } \\
\text { (Medina \& Schneider, 2018) } \\
\text { Data on informal economy in Algeria from 2016 } \\
\text { to 2018 were taken from Kahina \& Saïd, 2020 }\end{array}$ \\
\hline $\begin{array}{l}\text { Growth } \\
\text { Rate }\end{array}$ & $\begin{array}{l}\text { Annual percentage growth rate } \\
\text { of GDP at market prices based } \\
\text { on constant local currency }\end{array}$ & $\begin{array}{l}\text { World Bank } \\
\text { https://databank.worldbank.org/home.aspx }\end{array}$ \\
\hline
\end{tabular}

\section{EMPIRICAL RESULTS AND DISCUSSION}

\subsection{Unit Root Test}

Before the estimation of NARDL model, it is necessary to examine the stationary variables of the study. Using Eviews11 software, we examined the stationary variables using ADF test developed by Dickey \& Fuller (1979), PP test developed by Phillips and Perron (1988), and KPSS test developed by Kwiatkowski et al. (1992). These tests showed that all variables were stationary at the level or at the first difference (view appendix). It means that variables meet the requirements for building NARDL model developed by Shin et al. (2014).

Based on the results of unit root test, and trying to investigate the long-run and the short-run relationships between FDI and IE, in our case we will rely on the NARDL model.

\subsection{Diagnostics Tests}

The strength of models were defined using some statistic tests, such as Breusch-Godfrey serial correlation LM test developed by Breusch \& Pagan (1980) to test the serial correlation; ARCH test developed by Engle (1982), Jarque-Bera normality test (Jarque \& Bera, 1987), and Ramsey RESET (Ramsey, 1969).

As shown in Table 2, $F_{\text {prob }}$ and $\chi^{2}$ are greater than $5 \%$ in the case of Algeria and Saudi Arabia; $F_{\text {prob }}$ and $\chi^{2}$ are greater than $10 \%$ in the case of Norway, the Russian Federation and the United States. It appears that models do not suffer from problems of serial correlation. 
Table 2. Breusch-Godfrey Serial Correlation LM Tests

\begin{tabular}{|l|l|l|l|l|l|}
\hline \multicolumn{1}{|c|}{ Country } & $\boldsymbol{F}_{\text {stat }}$ & $\boldsymbol{F}_{\text {prob }}$ & $\boldsymbol{O b \boldsymbol { S } * \boldsymbol { R } ^ { \mathbf { 2 } }}$ & \multicolumn{1}{|c|}{$\boldsymbol{X}^{\mathbf{2}}$} & \multicolumn{1}{c|}{ Decision } \\
\hline Algeria & 0.805 & 0.451 & 2.012 & 0.366 & $\begin{array}{l}H_{0} \text { is accepted; there is no serial } \\
\text { correlation at the 5 \% level }\end{array}$ \\
\hline Norway & 0.135 & 0.873 & 0.423 & 0.809 & $\begin{array}{l}H_{0} \text { is accepted; there is no serial } \\
\text { correlation at the 10\% level }\end{array}$ \\
\hline $\begin{array}{l}\text { The } \\
\text { Russian } \\
\text { Federation }\end{array}$ & 1.632 & 0.206 & 5.475 & 0.647 & $\begin{array}{l}H_{0} \text { is accepted; there is no serial } \\
\text { correlation at the 10\% level }\end{array}$ \\
\hline $\begin{array}{l}\text { Saudi } \\
\text { Arabia }\end{array}$ & 4.145 & 0.0245 & 17.054 & 0.010 & $\begin{array}{l}H_{0} \text { is accepted; there is no serial } \\
\text { correlation at the 5\% level }\end{array}$ \\
\hline $\begin{array}{l}\text { The United } \\
\text { States }\end{array}$ & 1.320 & 0.273 & 3.489 & 0.175 & $\begin{array}{l}H_{0} \text { is accepted; there is no serial } \\
\text { correlation at the 10\% level }\end{array}$ \\
\hline
\end{tabular}

ARCH test clearly indicates that $F_{\text {prob }}$ is greater than $10 \%$ for all five models (see Table 3). It means the null hypothesis is rejected, thus demonstrating absence of conditional heteroscedasticity.

Table 3. Heteroskedasticity, ARCH Test

\begin{tabular}{|l|l|l|l|l|l|}
\hline \multicolumn{1}{|c|}{ Country } & $\boldsymbol{F}_{\text {stat }}$ & $\boldsymbol{F}_{\text {prob }}$ & $\boldsymbol{O b \boldsymbol { b } * \boldsymbol { R } ^ { \mathbf { 2 } }}$ & \multicolumn{1}{|c|}{$\boldsymbol{X}^{\mathbf{2}}$} & \multicolumn{1}{c|}{ Decision } \\
\hline Algeria & 0.9479 & 0.3326 & 0.9579 & 0.3277 & $\begin{array}{l}H_{0} \text { is accepted; there is long-run } \\
\text { equilibrium relationship at the 10\% } \\
\text { level }\end{array}$ \\
\hline Norway & 0.4829 & 0.4891 & 0.4914 & 0.4833 & $\begin{array}{l}H_{0} \text { is accepted; there is long-run } \\
\text { equilibrium relationship at the 10\% } \\
\text { level }\end{array}$ \\
\hline $\begin{array}{l}\text { The } \\
\text { Russian } \\
\text { Federation }\end{array}$ & 2.4174 & 0.1711 & 2.2786 & 0.1613 & $\begin{array}{l}H_{0} \text { is accepted; there is long-run } \\
\text { equilibrium relationship at the } \\
10 \% \text { level }\end{array}$ \\
\hline $\begin{array}{l}\text { Saudi } \\
\text { Arabia }\end{array}$ & 3.4364 & 0.2354 & 2.8593 & 0.1956 & $\begin{array}{l}H_{0} \text { is accepted; there is long-run } \\
\text { equilibrium relationship at the 1\% } \\
\text { level }\end{array}$ \\
\hline $\begin{array}{l}\text { The United } \\
\text { States }\end{array}$ & 0.4931 & 0.4834 & 0.5053 & 0.4779 & $\begin{array}{l}H_{0} \text { is accepted; there is long-run } \\
\text { equilibrium relationship at the } \\
10 \% \text { level }\end{array}$ \\
\hline
\end{tabular}

Jarque-Bera test is used to examine whether the residuals are normally distributed. According to test results shown in Table 4, in the case of this study, $P$-value is greater than $1 \%$ for all models, which means that in all equations the hypothesis $H_{0}$ of normal distribution of the residuals cannot be rejected. 
Table 4. Jarque-Bera Test

\begin{tabular}{|l|l|l|l|}
\hline \multicolumn{1}{|c|}{ Country } & \multicolumn{1}{|c|}{ JB } & \multicolumn{1}{|c|}{ Prob } & \multicolumn{1}{c|}{ Decision } \\
\hline Algeria & 4.1889 & 0.021 & $\begin{array}{l}H_{0} \text { is accepted; residuals are normally distributed at the } \\
1 \% \text { level }\end{array}$ \\
\hline Norway & 3.2594 & 0.014 & $\begin{array}{l}H_{0} \text { is accepted; residuals are normally distributed at the } \\
1 \% \text { level }\end{array}$ \\
\hline $\begin{array}{l}\text { The } \\
\text { Russian } \\
\text { Federation }\end{array}$ & 3.7381 & 0.041 & $\begin{array}{l}H_{0} \text { is accepted; residuals are normally distributed at the } \\
1 \% \text { level }\end{array}$ \\
\hline $\begin{array}{l}\text { Saudi } \\
\text { Arabia }\end{array}$ & 3.7921 & 0.038 & $\begin{array}{l}H_{0} \text { is accepted; residuals are normally distributed at the } \\
1 \% \text { level }\end{array}$ \\
\hline $\begin{array}{l}\text { The United } \\
\text { States }\end{array}$ & 2.7514 & 0.041 & $\begin{array}{l}H_{0} \text { is accepted; residuals are normally distributed at the } \\
1 \% \text { level }\end{array}$ \\
\hline
\end{tabular}

Table 5 shows the results of Ramsey REST test. It is clear that $P$-values of $T_{\text {stat }}$ and $F_{\text {stat }}$ are largely greater than $10 \%$ for all models; the hypothesis $H_{0}$ which states that the model is correctly specified is acceptable for the five models.

Table 5. Ramsey RESET Test

\begin{tabular}{|c|c|c|c|c|c|}
\hline Country & Statistic test & Value & DF & Prob & Decision \\
\hline \multirow{3}{*}{ Algeria } & $T_{\text {stat }}$ & 0.182 & 81 & 0.856 & \multirow{3}{*}{$\begin{array}{l}H_{0} \text { is rejected; there is long-run } \\
\text { equilibrium relationship at the } \\
10 \% \text { level }\end{array}$} \\
\hline & $F_{\text {stat }}$ & 0.032 & $(1,81)$ & 0.856 & \\
\hline & Lkelihood ratio & 0.041 & 1 & 0.838 & \\
\hline \multirow{3}{*}{ Norway } & $T_{\text {stat }}$ & 0.258 & 57 & 0.798 & \multirow{3}{*}{$\begin{array}{l}H_{0} \text { is rejected; there is long-run } \\
\text { equilibrium relationship at the } \\
10 \% \text { level }\end{array}$} \\
\hline & $F_{\text {stat }}$ & 0.066 & $(1,57)$ & 0.798 & \\
\hline & Lkelihood ratio & 0.102 & 1 & 0.749 & \\
\hline \multirow{3}{*}{$\begin{array}{l}\text { The } \\
\text { Russian } \\
\text { Federation }\end{array}$} & $T_{\text {stat }}$ & 0.919 & 49 & 0.362 & \multirow{3}{*}{$\begin{array}{l}H_{0} \text { is rejected; there is long-run } \\
\text { equilibrium relationship at the } \\
10 \% \text { level }\end{array}$} \\
\hline & $F_{\text {stat }}$ & 0.845 & $(1,49)$ & 0.362 & \\
\hline & Lkelihood ratio & 1.470 & 1 & 0.225 & \\
\hline \multirow{3}{*}{$\begin{array}{l}\text { Saudi } \\
\text { Arabia }\end{array}$} & $T_{\text {stat }}$ & 1.398 & 35 & 0.171 & \multirow{3}{*}{$\begin{array}{l}H_{0} \text { is rejected; there is long-run } \\
\text { equilibrium relationship at the } \\
10 \% \text { level }\end{array}$} \\
\hline & $F_{\text {stat }}$ & 1.954 & $(1,35)$ & 0.171 & \\
\hline & Lkelihood ratio & 4.727 & 1 & 0.030 & \\
\hline \multirow{3}{*}{$\begin{array}{l}\text { The United } \\
\text { States }\end{array}$} & $T_{\text {stat }}$ & 0.901 & 68 & 0.011 & \multirow{3}{*}{$\begin{array}{l}H_{0} \text { is rejected; there is long-run } \\
\text { equilibrium relationship at the } \\
10 \% \text { level }\end{array}$} \\
\hline & $F_{\text {stat }}$ & 0.895 & $(1,68)$ & 0.013 & \\
\hline & Lkelihood ratio & 0.884 & 1 & 0.013 & \\
\hline
\end{tabular}

\subsection{The Bound Test for Nonlinearity}

The empirical results of bounds test for co-integration revealed that the computed $F_{\text {stat }}$ for the Algerian model was above the upper bounds at $10 \%$ level; for Norway, the Russian Federation and the United States the computed $F_{\text {stat }}$ fell 
above the upper bounds at $5 \%$ level; also, it is above the upper bounds in the models of Arabia Saudi. Based on results shown in Table 6, the null hypothesis $H_{0}$ of nocointegration is rejected, which implies the existence of long-run relationships between FDI, IE and growth rate.

Table 6. The Bound Test for Nonlinearity

\begin{tabular}{|c|c|c|c|c|c|}
\hline \multirow{2}{*}{ Country } & \multirow{2}{*}{$\begin{array}{l}\text { Level of } \\
\text { significance }\end{array}$} & \multicolumn{2}{|c|}{$F_{\text {table }}$} & \multirow{2}{*}{$F_{\text {stat }}$} & \multirow{2}{*}{ Decision } \\
\hline & & $I(0)$ & $I(1)$ & & \\
\hline \multirow{4}{*}{ Algeria } & $10 \%$ & 2.37 & 3.20 & \multirow{4}{*}{3.49} & \multirow{4}{*}{$\begin{array}{l}H_{0} \text { is rejected; there is long-run } \\
\text { equilibrium relationship at the } 10 \% \text { level }\end{array}$} \\
\hline & $5 \%$ & 2.79 & 3.67 & & \\
\hline & $2.50 \%$ & 3.15 & 4.08 & & \\
\hline & $1 \%$ & 3.65 & 4.66 & & \\
\hline \multirow{4}{*}{ Norway } & $10 \%$ & 2.37 & 3.20 & \multirow{4}{*}{4.03} & \multirow{4}{*}{$\begin{array}{l}H_{0} \text { is rejected; there is long-run } \\
\text { equilibrium relationship at the } 5 \% \text { level }\end{array}$} \\
\hline & $5 \%$ & 2.79 & 3.67 & & \\
\hline & $2.50 \%$ & 3.15 & 4.08 & & \\
\hline & $1 \%$ & 3.65 & 4.66 & & \\
\hline \multirow{4}{*}{$\begin{array}{l}\text { The } \\
\text { Russian } \\
\text { Federation }\end{array}$} & $10 \%$ & 2.37 & 3.20 & \multirow{4}{*}{3.89} & \multirow{4}{*}{$\begin{array}{l}H_{0} \text { is rejected; there is long-run } \\
\text { equilibrium relationship at the } 5 \% \text { level }\end{array}$} \\
\hline & $5 \%$ & 2.79 & 3.67 & & \\
\hline & $2.50 \%$ & 3.15 & 4.08 & & \\
\hline & $1 \%$ & 3.65 & 4.66 & & \\
\hline \multirow{4}{*}{$\begin{array}{l}\text { Saudi } \\
\text { Arabia }\end{array}$} & $10 \%$ & 2.37 & 3.20 & \multirow{4}{*}{4.55} & \multirow{4}{*}{$\begin{array}{l}H_{0} \text { is rejected; there is long-run } \\
\text { equilibrium relationship at the } 5 \% \text { level }\end{array}$} \\
\hline & $5 \%$ & 2.79 & 3.67 & & \\
\hline & $2.50 \%$ & 3.15 & 4.08 & & \\
\hline & $1 \%$ & 3.65 & 4.66 & & \\
\hline \multirow{4}{*}{$\begin{array}{l}\text { The } \\
\text { United } \\
\text { States }\end{array}$} & $10 \%$ & 2.37 & 3.20 & \multirow{4}{*}{4.05} & \multirow{4}{*}{$\begin{array}{l}H_{0} \text { is rejected; there is long-run } \\
\text { equilibrium relationship at the } 5 \% \text { level }\end{array}$} \\
\hline & $5 \%$ & 2.79 & 3.67 & & \\
\hline & $2.50 \%$ & 3.15 & 4.08 & & \\
\hline & $1 \%$ & 3.65 & 4.66 & & \\
\hline
\end{tabular}

\subsection{NARDL Models for Long-run and Short-run Analysis}

Based on the diagnostic test and bounds test results reported in Tables 2-6, it can be said that the NARDL model is applicable in each case of the sample.

The empirical results reveal that for Algeria and Saudi Arabia, FDI inflows are positively affected by positive shocks of the IE, where an increase by one unit in the IE lead to an increase by $1.7 \%$ and $67.9 \%$ in the FDI inflows, respectively. The negative shocks also positively affect the FDI inflows. If the IE decreases by one unit, the FDI inflows will increase by $9.2 \%$ and $102.1 \%$, respectively. The economic growth rate has a positive effect on the FDI inflows; thus, a change in the economic growth by one unit leads to a change in the FDI inflows by $1.2 \%$ and $21.1 \%$, respectively. 
Table 7. NARDL Models for Long-run Analysis

\begin{tabular}{|c|c|c|c|c|}
\hline Country & Variable & Coefficient & $T_{\text {stat }}$ & Prob \\
\hline \multirow{5}{*}{ Algeria } & $P O S^{* * *}$ & 0.017 & 0.296280 & 0.04 \\
\hline & $I E \_N E G^{* *}$ & 0.092 & 0.625333 & 0.252 \\
\hline & $G R^{* *}$ & 0.012 & 0.234778 & 0.037 \\
\hline & $C$ & 2.095 & 1.162453 & 0.074 \\
\hline & \multicolumn{4}{|c|}{$F D I=2.095+0.017 I E^{+}+0.092 I E^{-}+0.012$ Growth } \\
\hline \multirow{5}{*}{ Norway } & $I E \_P O S^{*}$ & -1.419 & -3.810130 & 0 \\
\hline & $I E \_N E G^{*}$ & 1.301 & 3.563975 & 0 \\
\hline & $G R$ & 0.729 & 1.380623 & 0.825 \\
\hline & $C$ & -1.086 & -0.494083 & 0.048 \\
\hline & \multicolumn{4}{|c|}{$F D I=-1.056-1.419 I E^{+}+1.301 I E^{-}+0.729$ Growth } \\
\hline \multirow{5}{*}{$\begin{array}{l}\text { The Russian } \\
\text { Federation }\end{array}$} & $I E \_P O S$ & -0.444 & -0.307762 & 0.055 \\
\hline & $I E \_N E G^{* * *}$ & 0.011 & 0.017511 & 0.37 \\
\hline & $G R^{* *}$ & 0.671 & 0.459377 & 0.074 \\
\hline & $C$ & 9.652 & 0.380752 & 0.169 \\
\hline & \multicolumn{4}{|c|}{$F D I=9.652-0.444 I E^{+}+0.011 I E^{-}+0.671$ Growth } \\
\hline \multirow{5}{*}{ Saudi Arabia } & $I E \_P O S^{*}$ & 0.679 & 3.399254 & 0.765 \\
\hline & $I E \_N E G^{*}$ & 1.021 & 3.404450 & 0.062 \\
\hline & $G R^{* *}$ & 0.211 & 0.636277 & 0.04 \\
\hline & $C^{*}$ & 4.621 & 3.398849 & 0.683 \\
\hline & \multicolumn{4}{|c|}{$F D I=4.621+0.679 I E^{+}+1.021 I E^{-}+0.211$ Growth } \\
\hline \multirow{4}{*}{$\begin{array}{l}\text { The United } \\
\text { States }\end{array}$} & $I E \_P O S$ & -0.242 & -0.416420 & 0.07 \\
\hline & $I E \_N E G^{* * *}$ & 0.376 & 0.743559 & 0.64 \\
\hline & $G R^{* * *}$ & 0.422 & 0.904898 & 0.095 \\
\hline & $C^{* * *}$ & -0.349 & -0.170440 & 0.094 \\
\hline
\end{tabular}

In case of Norway, the Russian Federation and the United States, FDI inflows are affected negatively by positive shocks of the IE size, and they are positively affected by the negative ones, where an increase in the size of IE by one unit leads to a decrease in FDI inflows by $141.9 \%, 44.4 \%$ and $24.2 \%$, respectively. When the IE size moves in the opposite direction, the FDI inflows will increase by $130.1 \%, 1.1 \%$ and $37.6 \%$, respectively. FDI inflows are positively affected by the economic growth rate in the case of Norway, the Russian Federation and the United States, where one unit of change in the economic growth rate leads to a change by $72.9 \%, 21.1 \%$ and $42.2 \%$, respectively. 
Table 8. NARDL Models for Short-run Analysis

\begin{tabular}{|c|c|c|c|c|c|}
\hline Country & Variable & Coefficient & Std.Error & $T_{\text {stat }}$ & Prob \\
\hline \multirow{6}{*}{ Algeria } & $\mathrm{D}(\mathrm{FDI}(-1))$ & 0.614 & 0.089 & 6.883 & 0.000 \\
\hline & $\mathrm{D}(\mathrm{FDI}(-2))$ & 0.140 & 0.090 & 1.546 & 0.125 \\
\hline & D(IE_POS) & 0.042 & 0.049 & 0.849 & 0.397 \\
\hline & D(IE_POS(-1)) & 0.098 & 0.051 & 1.896 & 0.060 \\
\hline & D(IE_NEG) & 0.096 & 0.057 & 1.674 & 0.097 \\
\hline & CointEq(-1)* & -0.039 & 0.009 & -4.149 & 0.000 \\
\hline \multirow{6}{*}{ Norway } & $\mathrm{D}(\mathrm{FDI}(-1))$ & 0.416 & 0.108 & 3.843 & 0.000 \\
\hline & $\mathrm{D}(\mathrm{FDI}(-2))$ & 0.227 & 0.116 & 1.953 & 0.055 \\
\hline & D(IE_NEG) & 0.536 & 0.335 & 1.600 & 0.114 \\
\hline & $\mathrm{D}(\mathrm{GR})$ & 1.257 & 0.128 & 9.762 & 0.000 \\
\hline & $\mathrm{D}(\mathrm{GR}(-1))$ & -0.462 & 0.200 & -2.310 & 0.024 \\
\hline & CointEq(-1)* & -0.235 & 0.050 & -4.646 & 0.000 \\
\hline \multirow{6}{*}{$\begin{array}{l}\text { The Russian } \\
\text { Federation }\end{array}$} & $\mathrm{D}(\mathrm{FDI}(-1))$ & 0.860 & 0.081 & 10.53 & 0.000 \\
\hline & D(IE_POS) & 0.352 & 0.049 & 7.123 & 0.000 \\
\hline & D(IE_POS(-1)) & -0.299 & 0.057 & -5.162 & 0.000 \\
\hline & D(IE_NEG) & -0.074 & 0.039 & -1.917 & 0.060 \\
\hline & $\mathrm{D}(\mathrm{GR})$ & 0.099 & 0.011 & 8.560 & 0.000 \\
\hline & CointEq(-1)* & -0.013 & 0.006 & -2.200 & 0.032 \\
\hline \multirow{11}{*}{ Saudi Arabia } & $\mathrm{D}(\mathrm{FDI}(-1))$ & 2.183 & 0.097 & 22.419 & 0.000 \\
\hline & $\mathrm{D}(\mathrm{FDI}(-2))$ & 1.915 & 0.244 & 9.840 & 0.000 \\
\hline & D(IE_POS) & 0.005 & 0.000 & 7.250 & 0.000 \\
\hline & D(IE_POS(-1)) & 0.071 & 0.007 & 9.432 & 0.000 \\
\hline & D(IE_POS(-2)) & 0.067 & 0.007 & 8.910 & 0.000 \\
\hline & D(IE_NEG) & 0.001 & 0.000 & 1.766 & 0.085 \\
\hline & D(IE_NEG(-1)) & 0.074 & 0.008 & 9.258 & 0.000 \\
\hline & D(IE_NEG(-2)) & 0.064 & 0.007 & 8.695 & 0.000 \\
\hline & $\mathrm{D}(\mathrm{GR})$ & 0.161 & 0.020 & 7.788 & 0.000 \\
\hline & $\mathrm{D}(\mathrm{GR}(-1))$ & 0.291 & 0.048 & 6.003 & 0.000 \\
\hline & CointEq(-1)* & -0.010 & 0.001 & -9.342 & 0.000 \\
\hline \multirow{9}{*}{$\begin{array}{l}\text { The United } \\
\text { States }\end{array}$} & $\mathrm{D}(\mathrm{FDI}(-1))$ & 0.688 & 0.087 & 7.837 & 0.000 \\
\hline & $\mathrm{D}(\mathrm{FDI}(-2))$ & 0.107 & 0.082 & 1.299 & 0.198 \\
\hline & D(IE_POS) & 0.405 & 0.124 & 3.264 & 0.001 \\
\hline & D(IE_POS(-1)) & 0.352 & 0.126 & 2.782 & 0.007 \\
\hline & D(IE_NEG) & -0.171 & 0.039 & -4.365 & 0.000 \\
\hline & D(IE_NEG(-1)) & 0.152 & 0.044 & 3.453 & 0.000 \\
\hline & $\mathrm{D}(\mathrm{GR})$ & 0.216 & 0.032 & 6.764 & 0.000 \\
\hline & $\mathrm{D}(\mathrm{GR}(-1))$ & -0.155 & 0.038 & -4.055 & 0.000 \\
\hline & CointEq(-1)* & -0.070 & 0.021 & -3.295 & 0.001 \\
\hline
\end{tabular}


The most interesting finding in the short-run analysis is that the FDI inflows response positively to FDI inflows lagged to two periods for the whole sample except the Russian Federation, where the FDI inflows response positively to FDI inflows lagged to just one period. FDI inflows are also affected by the positive shocks of the size of the IE lagged to one period in Algeria, the Russian Federation and the United States, and it is affected by the positive shocks lagged to two periods in the case of Saudi Arabia. The positive shocks of IE do not have an effect on FDI inflows in Norway in the short-run analysis. FDI inflows are affected by the negative IE shocks lagged to two periods in Saudi Arabia; they are affected by negative IE shocks lagged to just one period in the case of Algeria and the United States. In the case of Norway and the Russian Federation, they are affected just by instantaneous negative IE shocks. FDI inflows are affected by the economic growth rate lagged to just one period in the case of Norway, Saudi Arabia and the United States. In the case of the Russian Federation, they are affected just by instantaneous negative IE shocks; for Algeria the economic growth rate does not have an effect in the short-run analysis.

\section{FURTHER DISCUSSIONS}

The empirical results of long-run analysis allowed distinguishing between two subgroups of countries. The first subgroup consisted of countries where the FDI inflows took an upward trend, whatever the direction of the IE development. This subgroup consisted of Algeria and Saudi Arabia. The second subgroup was composed of countries where the FDI inflows were affected negatively by the positive shocks of the IE, and positively by the negative ones. It consisted of the following countries: Norway, the Russian Federation and the United states. The effects of IE varied from country to country inside each subgroup. Another important remark is that the FDI inflows were positively affected by the economic growth rate in all countries of the study sample.

It is surprising that the FDI inflow equation is an augmented equation in terms of both positive and negative shocks of the IE for Algeria and Saudi Arabia. These countries are depending on natural resources in their economies, and they are characterised by a high share of natural resources in their GDP, where Algeria and Saudi Arabia have enormous natural resources, especially hydrocarbons. The statistics shows that the hydrocarbons represented more than $90 \%$ of Algerian exports in 2019 (UNCTAD, 2021), and natural resources rent as a percentage of GDP was $31.6 \%$ and $19 \%$ in Algeria in 2011 and 2018, respectively (World bank, 2021). Inward FDI in the oil and gas industry and related fields represented $63.8 \%$ of global FDI inflows to Algeria in 2005 and it was $46.2 \%$ in 2009 (NAID, 2021). The statistics of the World Bank indicates that natural resources represented $50.5 \%$ and $29.5 \%$ in Saudi Arabia's GDP in 2011 and 2018 respectively. The investment in the oil and gas industry represented more than $37 \%$ of the global FDI inflows to Saudi Arabia in 2009 (SAGIA, 2010), and it was 22.45\% in 2004 and $64.3 \%$ in 2005 (ESCWA, 2007). As it is known, the investment in the oil and gas industry is more sensitive to the change in oil and gas prices in the international markets than any other factors; this leads to considering the effect of IE on investment in this 
sector as insignificant. Thus, FDI inflows are not affected by a change in the size of IE in economy featured by reliance on hydrocarbons. The augmented international demand on oil and gas in the period of 2004-2012, and a higher price of oil and gas during this period contributed to increasing international investments in the hydrocarbon sector in Algeria and Saudi Arabia. Regardless of the size of the IE in these countries, the multinational hydrocarbon companies have attempted to keep up the increasing global demand of hydrocarbons, and also to make bigger profits.

The inward FDI of the second subgroup (Norway, the Russian Federation and the United States) was affected negatively by positive shocks of the IE. It means that a higher size of IE leads to a lower inward FDI. The most common feature of this subgroup is the relative independence of these economies from natural resources, where natural resources rent did not exceed $2 \%$ of the US GDP, $5 \%$ of Norwegian GDP over the period of 1996-2019.

The international investment in the US economy exceeded 4363 billion USD, just 74 billion USD were destined to invest in activities related to the extraction and manufacture of natural resources which represented $1.69 \%$ of global FDI inflows to US in 2018 (OII, 2019). The Russian economy received about 150 billion dollars as FDI in 2017; $72 \%$ of this inward FDI was directed to economic activities other than those related to the extraction of natural resources. In the first quarter of 2020 (Q1-2020), the FDI inflows to the Russian Federation accounted for 40 billion USD and just 11.5 billion USD were destined to oil and gas sector, mining and quarrying, rubber and plastic idustry (Bank of Russia, 2021). The inward FDI of Norway was mainly directed to activities that were not related to mining, quarrying, oil and industry, just $22 \%$ of global inward FDI was directed to those activities in 2018 (OECD.Stat, 2021).

The short-run analysis shows that the current FDI inflows are related to FDI inflows in the previous periods (between one and two lagged periods), and this finding is economically justified, because investment is usually a multi-year process.

Based on the results of the short-run and long-run analysis, it is obvious that the effect of IE size on inward FDI is dependent on its structure, and also it is dependent on the structure of the FDI inflows in the case of Norway, the Russian Federation and the United States, which are characterised by diversification of their economies and the relative independence from natural resources. Trend change of the IE leads to a change in the trend of FDI inflows, but in the case of Algeria and Saudi Arabia, the inward FDI is positively affected by both positive and negative shocks of the IE.

\section{CONCLUSION AND POLICY IMPLICATIONS}

The main aim of this paper has been to investigate the impact of IE on FDI inflows for a sample of countries producing and exporting hydrocarbons (Algeria, Norway, the Russian Federation, Saudi Arabia, and the United States) by exploring the effect of both positive and negative shocks of IE, using the NARDL methodology. The NARDL model was built for each country separately. The 
empirical results show that in countries characterised by a high share of natural resources rents in GDP (Algeria and Saudi Arabia), the inward FDI is positively affected by positive and negative shocks of IE size, but in countries characterised by a low share of natural resources rents in GDP (Norway, the Russian Federation and the United States), the FDI inflows are negatively affected by positive shocks of IE size, and positively affected by negative shocks of the IE size. In the previous cases, the FDI inflows moved in the same trend with an economic growth rate.

It is good for Algeria and Saudi Arabia to attract more FDI inflows regardless of the size of IE, but it will be better if they maintain the same amount of attracted FDI associated with improvement of their economic freedom, and give more importance to reducingthe IE size. This can be done through:

- Liberating economic activity from restrictions;

- Ensuring more transparency in both governmental and political lives;

- Enactment of laws and regulations in order to give more protection for proprietary rights;

- Promoting investment in economic sectors out of those related to natural resources, such as tourism and new technologies;

- Exploiting hydrocarbon revenues in building new infrastructures and renovating the existing ones.

\section{REFERENCES}

Ali, M., \& Bohara, A. K. (2017). How Does FDI Respond to the Size of Shadow Economy: An Empirical Analysis under a Gravity Model Setting. Int. Economic Journal, 31(1), 1-20.

Alfalih, A. A., \& Bel Hadj, T. (2020). Asymmetric Effects Of Foreign Direct Investment On Employment In An Oil Producing Country: Do Human Capital, Institutions And Oil Rents Matter? Resources Policy, 70, 101919. https://doi.org/10.1016/j.resourpol.2020.101919

Alsan, M., Bloom, D. E., \& Canning, D. (2006). The effect of population health on foreign direct investment inflows to low- and middle-income countries. World Development, 34(4), 613-630. https://doi.org/10.1016/j.worlddev.2005.09.006

Apergis, N., Lyroudi, K., \& Vamvakidis, A. (2008). The relationship between foreign direct investment and economic growth: evidence from transition countries. Transition Studies Review, 15, 37-51. https://doi.org/10.1007/s11300-008-0177-0

Asiedu, E., \& Lien, D. (2011). Democracy, foreign direct investment and natural resources. Journal of International Economics, 84(1), 99-111. https://doi.org/10.1016/j.jinteco.2010.12.001

Awunyo-Vitor, D., \& Sackey, R. A. (2018). Agricultural sector foreign direct investment and economic growth in Ghana. Journal of Innovation and Entrepreneurship, 7(1), 1-15.

Bayar, Y., Remeikiene, R., Androniceanu, A., Gaspareniene, L., Jucevicius R. (2020). The Shadow Economy, Human Development and Foreign Direct Investment Inflows. Journal of Competitiveness, 12(1), 5-21. https://doi.org/10.7441/joc.2020.01.01

Bank of Russia. (2021). External Sector Statistics. Retrieved 02 02, 2021, from Bank of Russia: http://www.cbr.ru/eng/statistics/macro_itm/svs/

Berdiev, A. N., Saunoris, J. W., \& Schneider, F. (2018). Give Me Liberty, or I Will Produce Underground: Effects of Economic Freedom on the Shadow Economy. Southern Economic Journal, 537-562. https://doi.org/10.1002/soej.12303

Bradley, F. (2005). International marketing strategy. Prentice Hall.

Breusch, T., \& Pagan, A. (1980). The Lagrange Multiplier Test and its Applications to Model Specification in Econometrics. The Review of Economic Studies, 47(1), 239-253. https://doi.org/10.2307/2297111

Cuong, H. V., Luu, H. N., \& Tuan, L. Q. (2020). The impact of the shadow economy on foreign direct investment. Applied Economics Letters, 28(5), 391-396. 
Davies, R.B., Siedschlag, I., \& Studnicka, Z. (2021). The impact of taxes on the extensive and intensive margins of FDI. International Tax and Public Finance, 28, 434-464.

Desbordes, R., \& Wei, S.-J. (2017). The effects of financial development on foreign direct investment. Journal of Development Economics, 127, 153-168. https://doi.org/10.1016/j.jdeveco.2017.02.008

Dickey, D. A., \& Fuller, W. A. (1979). Distribution of The Estimators for Autoregressive Time Series with A Unit Root. Journal of The American Statistical Association, 74(366a), 427-431. https://doi.org/10.1080/01621459.1979.10482531

Engle, R. F. (1982). Autoregressive Conditional Heteroscedasticity with Estimates of the Variance of United Kingdom Inflation. Econometrica, 50(4), 987-1007. https://doi.org/10.2307/1912773

Enste, D. (2018). The shadow economy in industrial countries. IZA World of Labour, 127, 1-11. https://doi.org/10.15185/izawol.127.v2

ESCWA. (2007). Report on Foreign Direct Investment Inlfows in the Escwa Region. New York: Economic and Social Commission for Western Asia.

Feige, E. L. eds. (1989). The Underground Economies. Tax Evasion and Information Distortion. Cambridge University.

Frey, B. S., \& Pommerehne, W. W. (1984). The Hidden Economy: State and Prospects for Measurement. Review of Income and Wealth, 30(1), 1-23. https://doi.org/10.1111/j.14754991.1984.tb00474.x

Huynh, C. M., Nguyen, V. H. T., Nguyen, H. B., \& Nguyen, P. C. (2019). One-way effect or multiple-way causality: foreign direct investment, institutional quality and shadow economy? International Economics and Economic Policy, 17, 219-239. https://doi.org/10.1007/s10368019-00454-1

ILO. (2012). Statistical Update on Employment in the Informal Economy. Geneva: International Labour Office Department of Statistics.

Imad, A. M. (2002). Foreign direct investment. Palgrave.

Jarque, C. M., \& Bera, A. K. (1987). A Test for Normality of Observations and Regression Residuals. International Statistical Review, 55(2), 163-172. https://doi.org/10.2307/1403192

Jorge, M., Juan Carlos, M.-B., \& Wilson, P. (2003). Foreign investment in Mexico after economic reform. In K. J. Middlebrook, \& Z. Eduardo, Confronting Development (pp. 123-161). Stanford: Stanford University Press.

Kahina, C.-F., \& Saïd, S. (2020). Informal economy, government intervention and labour market in Algeria: An analysis by structural models. Economics Bulletin, 1178-1193.

Kheng, V., Sun, S., \& Anwar, S. (2016). Foreign Direct Investment and Human Capital in Developing Countries: A Panel Data Approach. Economic Change and Restructuring, 50, 341365. https://doi.org/10.1007/s10644-016-9191-0

Kuvvet, E. (2021). Anti-Corruption Courts and Foreign Direct Investments. International Review of Economics \& Finance, 72, 573-582. https://doi.org/10.1016/j.iref.2020.12.019

Kwiatkowski, D., Phillips, P. C.B., Schmidt, P. \& Shin, Y. (1992). Testing the null hypothesis of stationarity against the alternative of a unit root: How sure are we that economic time series have a unit root? Journal of Econometrics, 54(1-3), 159-178. https://doi.org/10.1016/03044076(92)90104-Y

Li, Q., Owen, E., \& Mitchell, A. (2018). Why Do Democracies Attract More or Less Foreign Direct Investment? A Metaregression Analysis. International Studies Quarterly, 62(3), 494-504. https://doi.org/10.1093/isq/sqy014

Lisi, G. (2015). Unemployment, Underground Economy and Economic Growth In A Matching Model Of Behavioural Economics. International Review of Economics, 63, 159-170. https://doi.org/10.1007/s12232-015-0247-7

Loayza, N. V. (2016). Informality in the Process of Development and Growth. The World Economy, 39(12), 1856-1916. https://doi.org/10.1111/twec.12480

McCloud, N., Delgado, M. S., \& Holmes, C. (2018). Does a stronger system of law and order constrain the effects of foreign direct investment on government size? European Journal of Political Economy, 55, 258-283. https://doi.org/10.1016/j.ejpoleco.2018.01.004

Medina, L., \& Schneider, F. (2018). Shadow Economies Around the World: What Did We Learn Over the Last 20 Years? IMF Working Paper No. 18/17. 
Michael, Y. (2018). The FDI and Economic Growth Controversy in Sub-Saharan Africa. In H. Almas, Determinants of Economic Growth in Africa (pp. 17-54). Palgrave Macmillan. https://doi.org/10.1007/978-3-319-76493-1_2

Muslija, A. (2018). Foreign Direct Investments and Economic Freedom in OECD Countries. International Journal of Economic Studies, 4, 51-59.

NAID. (2021). National Agency of Investment Development. Retrieved 02 2021, 01, from http://www.andi.dz/index.php/en/

Nikopour, H., Shah Habibullah, M., Schneider, F., \& Law, S. H. (2009). Foreign Direct Investment and Shadow Economy: A Causality Analysis Using Panel Data. MPRA Paper 14485.

OECD. (2009). OECD Benchmark Definition of Foreign Direct Investment. OECD.

OECD.Stat. (2021). OECD better policies for better lives. Retrieved 02 02, 2021, from https://data.oecd.org/fdi/fdi-flows.htm

OII. (2019). Foreign Direct Investment in the United States 2019, unprecedented competition in the global race for jobs. Washington: Organization for International Investment.

Osano, H. M., \& Koine P. W. (2016). Role of Foreign Direct Investment on Technology Transfer and Economic Growth in Kenya: A Case of The Energy Sector. Journal of Innovation and Entrepreneurship, 5, 31. https://doi.org/10.1186/s13731-016-0059-3

Osei, M. J., \& Kim, J. (2020). Foreign direct investment and economic growth: Is more financial development better? Economic Modelling, 93, 154-161. https://doi.org/10.1016/j.econmod.2020.07.009

Peres, M., Ameer, W., \& Xu, H. (2018). The Impact of Institutional Quality on Foreign Direct Investment Inflows: Evidence for Developed and Developing Countries. Economic ResearchEkonomska Istraživanja, 31(1), 626-644. https://doi.org/10.1080/1331677X.2018.1438906

Phillips, P. C., \& Perron, P. (1988). Testing for A Unit Root in Time Series Regression. Biometrika, 75(2), 335-346. https://doi.org/10.1093/biomet/75.2.335

Ramsey, J. B. (1969). Tests for Specification Errors in Classical Linear Least-Squares Regression Analysis. Journal of the Royal Statistical Society Series B (Methodological), 31(2), 350-371. https://doi.org/10.1111/j.2517-6161.1969.tb00796.x

Rehman, C. A., Ilyas, M., Alam, H. M., \& Akram, M. (2011). The Impact of Infrastructure on Foreign Direct Investment: The Case of Pakistan. International Journal of Business and Management, 6(5), 268-276. https://doi.org/10.5539/ijbm.v6n5p268

Ruge, M. (2010). Determinants and Size of The Shadow Economy - A Structural Equation Model. International Economic Journal, 24(4), 511-523. https://doi.org/10.1080/10168737.2010.525988

Sadikova, M., Faisal, F., \& Resatoglu, N. G. (2017). Influence of Energy Use, Foreign Direct Investment and Population Growth on Unemployment for Russian Federation. Procedia Computer Science, 120, 706-7011. https://doi.org/10.1016/j.procs.2017.11.299

SAGIA. (2010). Annual Report of FDI. Riyadh: Saudi Arabian General Investment Authority.

Schmerer, H.-J. (2014). Foreign direct investment and search unemployment: Theory and evidence. Int. Review of Economics \& Finance, 30, 41-56. https://doi.org/10.1016/j.iref.2013.11.002

Shin, Y., Yu, B., \& Greenwood-Nimmo, M. (2014). Modelling Asymmetric Cointegration and Dynamic Multipliers in a Nonlinear ARDL Framework. In Sickles R., Horrace W. (eds) Festschrift in Honour of Peter Schmidt. Springer. https://doi.org/10.1007/978-1-4899-8008-3_9

The Heritage Foundation. (2021). 2020 index of economic freedom. Retrieved 02 03, 2021, from The Heritage Foundation: https://www.heritage.org/index/explore?version=440

UNCTAD. (2021). United Nations Conference on Trade and Development. Retrieved 02 01, 2021, from https://unctadstat.unctad.org/countryprofile/generalprofile/en-gb/012/index.html

Williams, K. (2017). Foreign Direct Investment, Economic Growth, And Political Instability. Journal of Economic Development, 42(2), 17-37. https://doi.org/10.35866/caujed.2017.42.2.002

World bank. (2021). world development indicators. Retrieved 02 01, 2021, from https://databank.worldbank.org/reports.aspx?source=2\&series=SL.AGR.EMPL.FE.ZS\&country=\#

Yao, Y., Chen, G. S., \& Zhang, L. (2021). Local financial intermediation and foreign direct investment: Evidence from China. International Review of Economics \& Finance, 72, 198-216. https://doi.org/10.1016/j.iref.2020.12.003 


\section{AUTHORS' SHORT BIOGRAPHY}

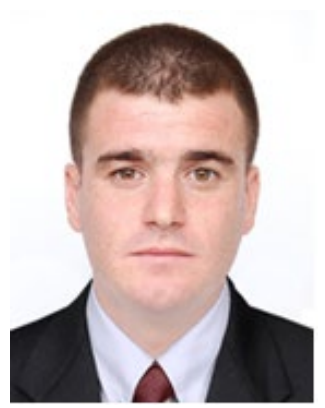

Ahmed Amine Zeddam State Engineer in Statistics at Provincial Treasury of ILLIZI, Ministry of Finance from 05/02/2013 to 14/09/2015; Senior Budget Inspector-Analyst at Budgetary Head Office, Ministry of Finance from 15/09/2015 to 10/12/2019; since 11/12/2019 a Management Planning Engineer at JV GAS (Sonatrach-BP Petroleum-Equinor). Obtained Diploma of State Engineer in Planning and Statistics, Option: Applied Statistics from The National Higher School of Statistics and Applied Economy, Algiers, In June 2012; and Diploma of Master in Statistics and Applied Economics, Option: Applied economics from the same institution in April 2013; in October 2017 he attended Djelali Liebes University, Sidi Bel Abbes, Algeria as PhD student, and he is preparing a thesis about the Algerian informal economy. e-mail: ahmed.zeddam@univ-sba.dz ORCID: https://orcid.org/0000-0001-5178-7286

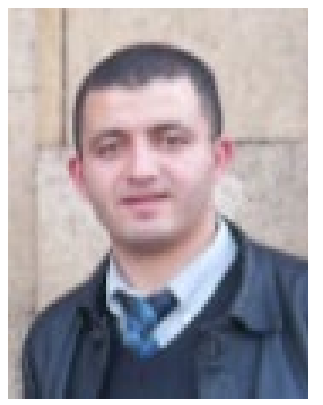

Pr. Mohamed Driouche Dahmani is professor of Economics at the University of Sidi Bel Abbes (Algeria). He earned a Bachelor in Money banking and finance (2003), Magister (2006) and a PhD in Economic Development at the University of Tlemcen in 2014; in January 2021, he attained the rank of Professor. He is lecturer at Djelali Liebes University, Sidi Bel Abbes, Algeria from 2008 till now. His main fields of specialization are economic development and growth, macroeconomics and energy economics. He is also interested in other areas of economics including econometrics and financial economics.

ORCID: https://orcid.org/0000-0003-2548-5238

e-mail: mohammed.dahmani@univ-sba.dz

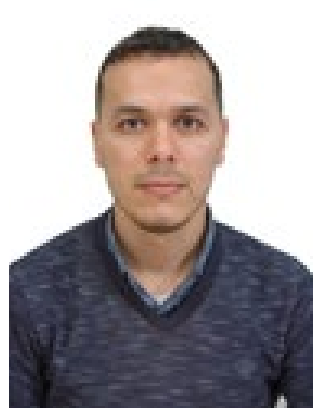

Abdelatif Hamrit a $\mathrm{PhD}$ student in Development Economics Option at Djelali Liebes University, Sidi Bel Abbes, Algeria, He has a master's degree in Applied Statistics and Econometrics (2016) from the National School of Statistics and Applied Economics, a bachelor's degree in Applied Economics (2013) from the University of M'sila, and a baccalaureate degree in mathematics (2010). He is interested in macroeconomics, econometrics, and Applied Statistics.

e-mail:abdelatif.hamriti@univ-sba.dz

ORCID: https://orcid.org/0000-0002-5872-2271 